\title{
Theoretical outline of supplier relationship management in conditions of economic uncertainty
}

\author{
Phd.Vlăduț Severian IACOB, Alma Mater din Sibiu, Romania
}

\begin{abstract}
Summary
Internet facilities have created new ways to identify, negotiate and engage suppliers and partners worldwide. Adding value to organizations, supply chain management aims at streamlining all processes and communication channels between them and their main suppliers, to facilitate effective interactions and flawless. Critical conditions generated by the current crisis grew and deepened the importance of supply chain management concept and the leading organizations realized that business partners might be a key element for their success. Meanwhile, global exchange of information can improve business processes for better access to resources.
\end{abstract}

\section{Key words}

Competitive environment, supply chain management, knowledge management, supply chain, CRM, SRM, SCM value chain.

\section{Introduction}

The current economic incertitude does not allow to create a future vision, but emphasizes the differences in global, regional, state level, and mainly at businesses. Its effects are destructive and lead to serious and impressive tone. Their impact reflects the general economic situation by sharpening the competitive relations or the spectacular bankruptcies and closures of companies and individuals who see themselves faced with job losses or assets and savings.

More limited purchasing options make possible permanent changes in the market resulting in a global competition between companies(Campelo and Stucky, 2007). Convulsions in new economic environment reconfigures competitive behavior, causing a revolution in the strategies of organizations. To overcome these challenges, it requires a reconsideration of their way of doing business based solely on internal resources to a dynamic strategy focused on broadening communication with business partners (Sethi, 2010). Such ongoing exchanges of information are going to get out the isolated firms integrating them into various value chains, especially under the impact of new technologies, especially those from information and communication field. Therefore, the acceptance and the introduction of new approaches to relations with stakeholders, use of information technology and electronic networks affiliation tend to be content elements of corporate strategy.

Increased competition in the economic hub puts additional emphasis on customers, not only to improve cash flow, but also to generate its best satisfaction to deep and strengthen relations within the supply chain (Burnet , 2004), making considerable efforts to understand their needs and desires. Viewed traditionally, the stated objectives outlined image of what in economic terms represents customer relationship management, but even if the companies emphasize their own customer relationship, it does not mean they do not take into account or that diminish the role of suppliers relationships. Creating and maintaining good supplier relations management involves adopting a philosophy to ensure compliance with essential characteristics: respect, partnership, growth and development, proper risk management, developing new capabilities (Donoghue, 2011). 
It should be noted that the option of companies to choose between suppliers and develop skills for identifying opportunities generate some costs related to creating and maintaining relationships. These costs are high regardless of the type of relationship: intermediate or partnership. Consistent benefit balance is achieved in the short or long term. Choosing a wrong relationship may result in excess costs. On account of obtaining an advantage most companies have a major concern to coordinate activity (Ravi and Menzigian, 2003), especially taking account of suppliers than customers, collaboration is more advantageous than the loss caused by interruption with supplier. An approach following laws, especially during the crisis, put in a new light Supplier Relationship Management (SRM) offering innovative perspectives on supply chain and transparency. Customers and suppliers are no longer a priority of maximizing short-term trading results, but follow through cooperation, long term mutual benefit. Companies willing to adopt this philosophy will have adequate time reward. They only have to accept to maintain credibility and commitment to start up businesses, especially in the globalized trade and accelerate the dynamic supply chains, focusing primarily on risk management.

\section{Outlines of the concept of Supplier relationship management (SRM)}

Defined as new category of solutions that enable manufacturers to optimize their relationships and expenses with suppliers (ITIL, 2001), supplier relationship management (SRM) is a relatively new term business since 1980, although before that time relations suppliers were explained either by 'logistics' and' joint operations or by similar expressions. Its adoption and use in businesses started in the $90 \mathrm{~s}$ as a way to streamline the business wishing to be considered a part of the development and organization of daily buyer-supplier relationship management as part of responsibilities within the flow of information in the supply chain.

At first sight it might be interpreted that supplier relationship management is just a subsystem (Eulálio, 2009) in the supply chain management (SCM), including both business practices and appropriate software (Bokhorst and all., 2006). but not only extends the principle of SRM supply management, but gives a different nuance of thought on how to work with suppliers, relying on greater transparency and sustained optimism, providing process improvement and increasing performances, which, associated with the purchase of goods and services, may lead to substantial savings through lower production costs, better quality and lower price of the final product.

Also, SRM practices provide a common frame of reference (Hald, Cordon and Vollmann, 2009) enabling effective communication between a company and its suppliers that may use different business practices and terminology content.

Supplier relationship management goal is to make more flexible and efficient deployment of time events, protocols, actions and transactions between a company and its suppliers, such as customer relationship management (CRM) is intended to streamline the process between a company and its customers.

\section{SRM Content and challenges}

Being connected with a high process flexibility, organizational perspective of SRM in all companies, particularly those with productive profile where philosophy just the right moment is adopted, has three essential elements: collaboration, integration and reliability (IDC, 2006, Donoghue, 2011). 


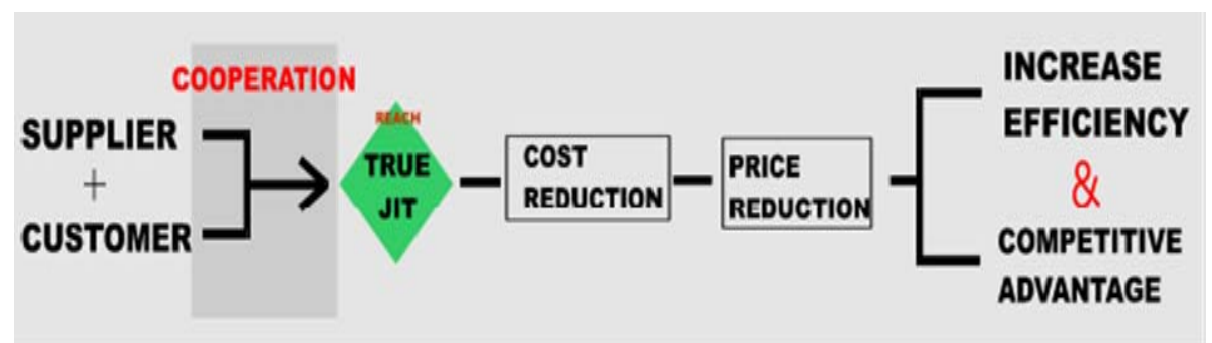

Fig.1 Just in time approach to partnership relationship with suppliers

Source: The partnership model: the type of buyer-supplier relation. http://html.rincondelvago.com

Policy of Just in Time (JIT) (Larson, 2005; Guerra and Cianchette, 2006) as a means of collaboration in organizations does not mean the relationship between companies is only the art of maintaining a balance between supply and demand, or only a mathematical rigor production process and perfect synchronization of supply in customer-supplier equation, but also the mutual benefit provided by implementing common applications that enable continuous exchange of information and better control over the management of long-term contracts. Such agreements may allow to suppliers the possibility of checking the availability of convenient solutions with customers, for example, stating the time limits for best price in the market. Such action may generate on the one hand, customer savings, on the other hand, guarantees for suppliers that goods remain in stock.

During the historical evolution of relations with suppliers, their integration involved great efforts mainly to achieve B2B (Wienclaw, 2008) programs, computer networks, the purchase and installation of software; the XXIst century IT boom managed to overcome many of the technical barriers of old companies providing real-time access to shared information (Sethi, 2010). In this respect, SRM deepens ties of dependency and mutual influence between the parties, creating synergy processes in the value chain, synthesizing best practices (Barry, Senthil and, Pradip, 2010) that requires the organization to comply. Thus, key business players, using a common portal of trade and marketing (e-marketplaces), enlarge their ebusiness concerns synchronizing processes, directly or indirectly, by connecting the companies. Thus, activation of these channels does not mean anything but integrating esourcing and e-procurement activities in B2B electronic market platform that uses Internet (Gartner, 2004) allowing large, medium and small corporations exchange of goods, services, and information in a more efficient and effective way than was previously possible.

From a theoretical perspective supplier relationship management has broad coverage and is not fully installed as a competence (Daley, 2009) in business management. SRM is more accepted and defined as a formal discipline (Evans, 2010). Lack of impact in organizations is fueled primarily by an identity crisis as a result of improper definition and poor integration of its functions in the work. Normally intended objectives are limited mainly to the cost of operating and risk management (Vliet, 2006) which makes the SRM may not appear as a source of competitive advantage. This happens frequently in organizations whose managers use a competency-based approach to develop critical skills and capabilities especially in supply problems, emphasizing weaker part relationship to increase management effectiveness. At the same time, managers are always given attention to make strong links with their suppliers recognizing that size relationship is important in creating value for the benefit of both parties. Success depends on the seriousness and commitment of each partner in achieving strategies. Such requests SRM acquisition and implementation skills, values and behaviors aligned not differentiate between providers.

Frequently, for an organization, the relationship with suppliers is directly related to the development of the product or service (Mettler and Rohner, 2009) and begins as a strategic sourcing initiative (Gecker, 2008) subsequently evolving data and performance indicators (Emiliani, 2010). As soon as the adaptation to changing requirements of end users is done, 
proximity to suppliers advances for the purpose of deepening collaboration and interaction (Lintukangas, 2007). Increased information exchange, increasing dependency accepting risk and frequency of the transactions are defining elements of collaboration. In this context, management of suppliers and relationships with them is effective if added value is obtained, as competitive advantage. For example, a product similar to the requirements of competition cannot be satisfied, either because of supply problems, either because they do not fit in costs or time resulting in discussion with the supplier of the redesign project. The same trend can register frequently relation to outsourced activities, usually when aiming to increase competitiveness and financial performance. Therefore SRM can be applied only when the company knows well the needs (Poirier, 2003) and has established requirements possibly has standardized nomenclature of products. This way no confusion or misunderstanding may occur regarding delivery of goods or services.

\section{Influence, behavior, trust, commitment}

Access to resources induce different behaviors of economic agents and consumers. They established many relationships based on challenges faced, trying to have some influence but without having any systematic and successful way (Pound, 2008) to do so. Each of economic actors are motivated and committed to a relationship as long as it goes well (Moldovan, 2006), both labor and effort are appreciated and their wishes and needs are taken into account. As relationships between individuals, in B2B relations, the done efforts create and maintain connections with a certain security. By accomplishing such a condition, it occurs growth and relationship building, contact supplier being considered as a result of how to build trust and loyalty. The supplier will know that encountering an obstacle, it will be supported in solving the problem arose. No less true is that in a SRM relationship may occur elements to spoil, to destabilize even to irreparably compromise it. Supplier may be overly familiar or suspicious and discussions may contain the same ideas, not inducing different viewpoints. Thus, a less good gradually degenerates into bad and the uncertainties that arise will generate motivation and state of recoil that will grind business security. On the same lines, the other partner, desiring change will produce persuasive act without substantive reasons for dissatisfaction surprise, trying to convince either by speech or policy or by various methods of restraint, something that may call into question the continued relationship. Occurrence of such situations requires the adoption, at organization and management level, of influencing models that are designed to change behavior and to facilitate overcoming or eliminating persistent and resistant problems. One of the models of the six sources of influence (Patterson, 2007), considers the motivations and skills on three levels (personal, social, structural) and involves the implementation of three steps: establishing a measurable result, finding a vital behavior, use the 6 sources of influence matrix (fig.nr.2).

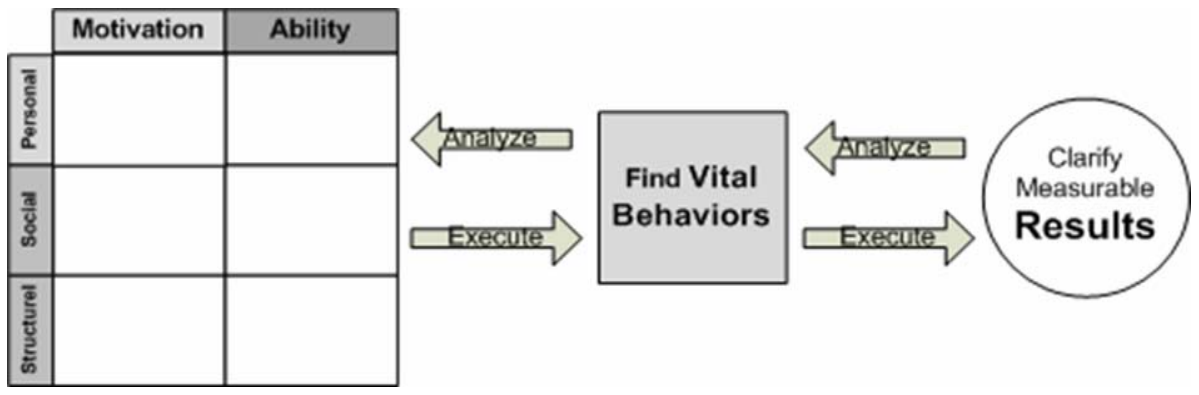

Fig.nr. 2 The steps of influencing

Source: Influencer - The Power to Change Anything, http://sourcesofinsight.com/influencer-the-power-to-changeanything 
By using this model they will be able to successfully establish the organization's mission and attitude change will be inevitable. Establishing more precise boundaries and clear rules on the relationship of SRM arrangement will remove any assumptions that the partner knew instinctively to accommodate the situation. Knowing the parameters of the relationship, perception of partner changes, even if the external circumstances remain unchanged. Even at the individual attitude change leads to a change in the perception of others.

Accepting a supplier implies to know him. As long as there is a thorough knowledge of the supplier or there is only incomplete information about him, the relationship with him is based on only a dose of confidence and hope to seriously address its obligations. Compliance provider fulfilling expectations in terms of understanding the other party. This behavior creates a certain state of safety and increased confidence. A business start with a low confidence level may generate uncertainty in expectations. In this respect, confidence building is a long process. It addresses in particular individuals who engage in such emotional relationship (Abosag, Tynan, Lewis, 2006) which affect the economic ties further. However, curdling trust claims politeness, friendship, empathy, similarity, honestly.

Studying organizational behavior, especially personal touch-organization in the early $1950 \mathrm{~s}$ enabled the emergence of the concept of engagement (Abrahamsson, 2002). Evolution and development of the concept of engagement, as presented today in the literature, is based on several studies, claims and disputes between researchers. Numerous definitions of engagement and measurement methods have been integrated in different models, the most commonly used model of organizational commitment are three components - affective commitment, normative commitment and engagement as proposed by Meyer and Allen (Meyer and Allen, 1991). Considering, in particular, connecting individuals to the organization mentioned model may be extended to all stakeholders not only to persons or suppliers. On the one hand, an emotional involvement implicit or explicit promise to continue the relationship (Dwyer, Schurr and Oh, 1987; Somogyi and Gyau, 2010), requires faith partners for any short-term sacrifices to maintain stability and efficiency (Gyau and Spiller, 2008), on the other hand, the adoption commitment by the supplier foresees a series of long-term benefits: quality products with lower cost information flow (Abosag, Tynan, Lewis , 2006). Therefore, commitment is central to economic relations between partners representing the amount engage different entities to work together for a common goal. Thus equated with growth or profitability, commitment is the force that drives the relationship forward (Vogele, 2009). However, commitment is hard to maintain because the parties are unable to see the scale start their actions. Accordingly, in the event there are all sorts of tensions commitment, resistance, and barriers were identified three major phases involved in change (Conner and Patterson 1982; Corner 1998), each of which is constructed by following some steps. (Fig.nr.3) 


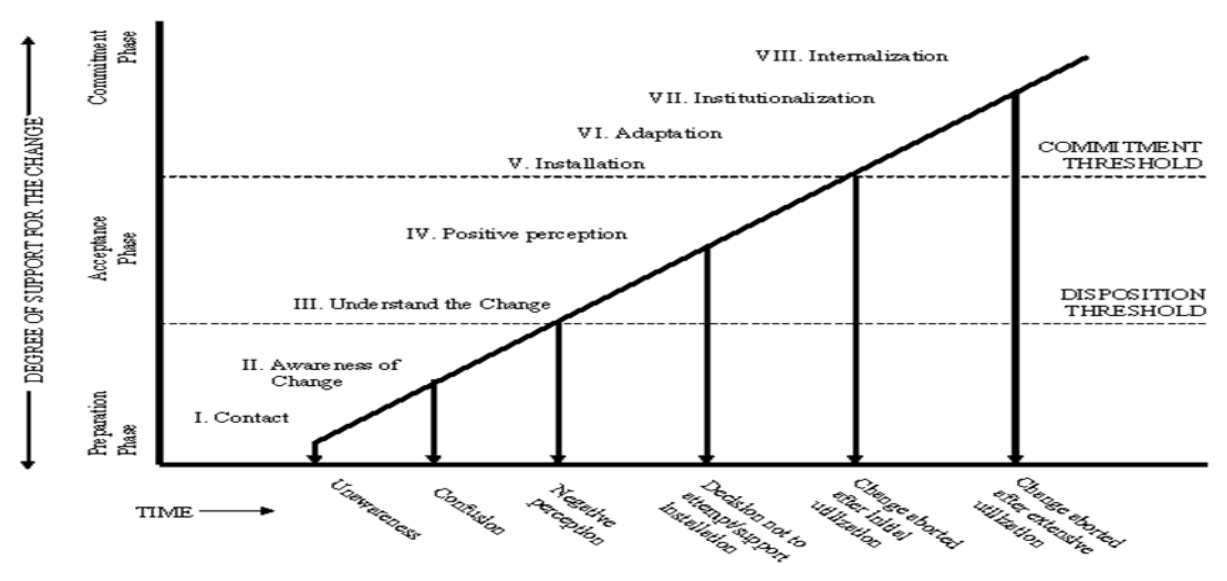

Fig. No. 3. Development (curve) commitment

Source: 1. Pekka Abrahamsson, (2002), The Role of Commitment in Software Process Improvement

\section{Types of collaboration and partnership}

Existence of global competition is putting a growing pressure on companies to become more competitive. Not being connected to this rate would cause the risk of business exit. Therefore, with the aim to obtain more value, higher, some companies may do wrong steps in choosing suppliers without identifying every time the 'key' suppliers.

After a series of authors collaborations with suppliers can be segmented in terms of level of cooperation in a mix of four levels (fig.nr.4) from low, combative at a very high supercollaboration (Billingt, Cordon, Volmanit, 2006), while according to others it is part of a process (fig.nr.5) also with four components (Lambert, 2008).

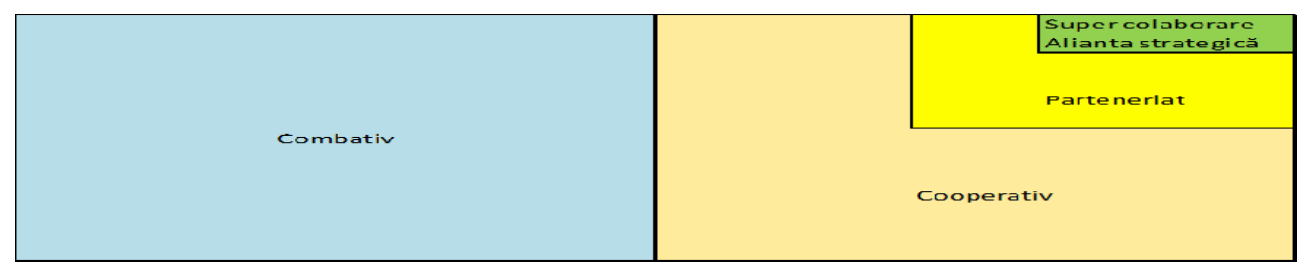

Fig.nr.4 typical mix of relationships with suppliers

Source: Corey Billington, Carlos Cordon, Tom Vollmann, 2006, Super Supplier Collaboration

In fact all refer to how deep is partners in a business relationship. The collaboration defines four components as follows: Length of arm, partnership, association, vertical integration.

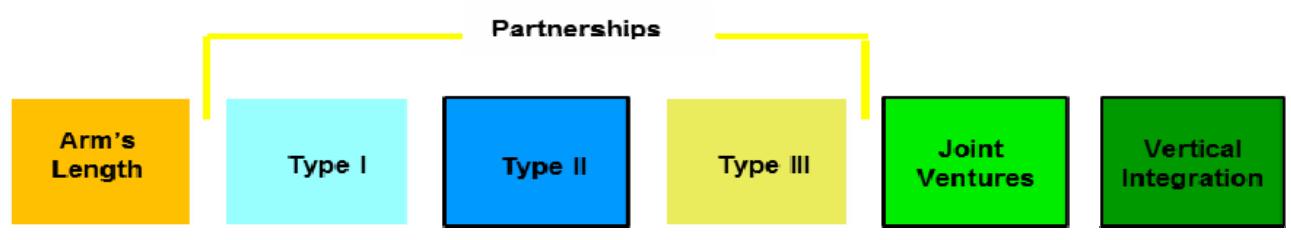

The collaboration Fig.nr.5

Source: Lambert, M.Douglas, Supply Chain Management: Processes, Partnerships, Performance, Sarasota, Florida: Supply Chain Management Institute, 2008 
Usual definition of partnership is that of business relationship based on mutual trust, openness, sharing risks and rewards arising in business (Lambert, Knemeyer, Gardner, 2004). Partnership requires high performance companies involved, more than would be achieved if they work separately. Creating and implementing a partnership entails use it for resources, both material and financial, as chosen by time, which is why such action is a challenge for managers. So it goes without saying that not all providers should be considered partners. Usually limited, resource allocation is made to those firms which will be a true partnership. Partnership relations may be varied and may take many forms depending on the organizational environment, all the circumstances affecting the business. Implementing, developing and improving relations with suppliers may be based on a partnership model involving assessment, formulation, consultation, implementation, negotiation. Any partnership model contains three types of partnership. Literature (Lambert, 2008) stipulates as follows:

- Type I - with the wider use and recognition as partners. Short-term approach.

- Type II - does not emphasize coordination of activities but more on their integration in a longer time horizon.

- Type III which requires a high level of operational integration.

The Partnership established by Lambert consists of three elements: engine (Drivers), catalyst (Facilitators), and components (Components). The three elements lead to an expected result by the parties.

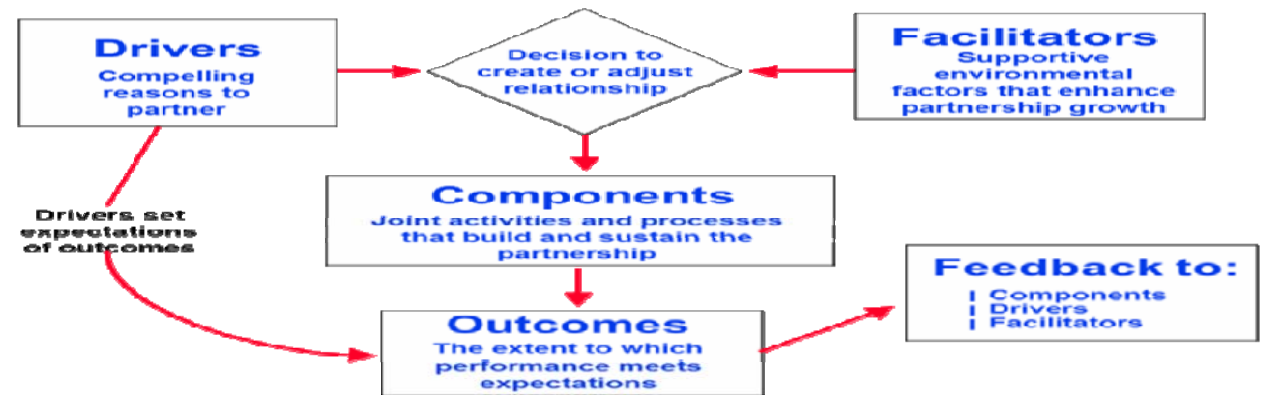

Fig.nr. 6 Model of Partnership

Source: Lambert, M.Douglas, Supply Chain Management: Processes, Partnerships, Performance, Sarasota, Florida: Supply Chain Management Institute, 2008

Driver elements are established after careful examination of potential parties counting on their belief in significant benefits by: (1) cost efficiency, (2) improve customer service, (3) marketing advantage and (4) before stability / growth.

Facilitator gives the existence of elements to enhance and develop partnership providing a basis for good relations while establishing materiality chance. Facilitators include: (1) corporate compatibility, (2) similar managerial philosophy and techniques, (3) reciprocity and (4) symmetry.

Component elements are mostly similar set of managerial actions and events that determines and dominates the life of the partnership. Components are operational relationship through: planning, control, communication, sharing of risks and rewards sharing etc.

Sharing of above elements leads to a result that implies an assessment, perhaps a readjustment. Feedback requires regular updating of state drivers, facilitators and components. Own processes and performance measurement provider enables companies to fully inform the partner, not only about the lowest price. 


\section{Conclusions}

Supplier relationship management is a relatively young discipline that has not been widely adopted in business. Dealing primarily with segmenting suppliers, establishing performance measurement tools and being currently limited to a series of e-processes, SRM is easily assimilated as part of the procurement chain (SCM). As such, in the next period SRM will remain stuck especially in the area of electronic research, the best prices and markets, as well as e-procurement, due to increasing interest from organizations for the installation of custom electronic systems for tracking processes. It is also the responsibility of managers to reconsider SRM and ensure strengthening current practices, especially regarding relations organization change in attitudes, the transfer of information, processes, outsourcing, procurement, contract tracking, etc. SRM adoption by organizations is part of a new management philosophy to increase the commitment and capacity of suppliers, to maintain a successful relationship with them.

\section{Bibliography}

1. AbrahamssonPekka, (2002), The Role of Commitment in Software Process Improvement, Academic Dissertation, Faculty of Science, University of Oulu, Linnanmaa, http://herkules. oulu. be/isbn9514267303/html/index. html, accessed 12. 10. 2012

2. Abosag Ibrahim, Caroline Tynan, Christopher Lewis, (2006), The Commitment-Trust Theory: The British and Saudi Arabian, Cross National perspectives, IMP Group. . -http://www. impgroup. org/uploads/papers/baby. pdf, accessed in 12. 10. 2012, 24 p.

3. Barry L. Senthil, G. , Pradip K, (2010), Best Practice: Supplier Stratification in Managing in an Uncertain Economy Council for Research on Distributor Best Practices (CRDBP), created by the NAW Institute for Distribution Excellence and the Supply Chain Systems Laboratory at Texas A\&M University nawinstitute. blogspot. com/. . . /best-practice-s

4. Billington Corey, Carlos Cordon, Tom Vollmann, 2006, Super Supplier Collaboration, in Perspectives for managers, http://m. imd. ch/research/publications/upload/PFM134_LR_Billingt_Cordon_Volmanpdf. pdf, accessed 12. 10. 2012, 4 p.

5. Bokhorst G. Frensch, C, N, Giling Kolk, (2006), Supplier Relationship Management Solutions: Expected Value, Capgemini Consulting Mario Like Utrecht in MS Research 2006-2007: Solution Analyses, www. capgemini. com/consulting accessed 25. 01. 2012, $60 \mathrm{p}$.

6. Burnet, Ken (2004). Supplier Relationships in Businessbriefing: Global Purchasing \& Supply Chain Strategies 2004 http://www. touchbriefings. com/pdf/199/ifpm032_p_burnett. pdf accessed in 10. 02. 2012, 3 p.

7. Campelo Eulálio Gomes, 2009. Analysis of Current Supplier Relationship Management Practices: Solution Proposal, Dissertation, Universität Karlsruhe, http://digbib. ubka. uni-karlsruhe. /volltexte/documents/926128, accessed 10. 02. 2012, 234p.

8. Campelo Eulálio G. F. and Stucky W. 2007. The Supplier Relationship Management Market Trends in the World Academy of Science, Engineering and Technology 28, http://www. 1343 BC. org/journals/1343 BC/v28/v28-20. pdf, accessed 09. 02. 2012

9. Daryl Conner and Robert Patterson, (1982), Building Commitment to Organizational Change,. Training and Development Journal, v36 n4. $15 \mathrm{p}$

10. Daryl Conner, (1998), Committing to change, Managing at the Speed of Change; How resilient managers succeed and prosper where others fail. \& John Wiley Sons, ISBN 0-471-97494-3, 14 p.

11. Daley, Andrew (2009) The growing importance of Supplier Relationship Management Edbury Daley Ltd, Carrington Business Park, Carrington, Manchester, M31 4DD, $24 \mathrm{p}$

12. Dwyer Robert, Paul Schurr, Oh Sejo, 1987. Developing Buyer-Seller Relationships. The Journal of Marketing, 54 (2), http://www. cob. butter. edu/SwartzS/slides/MKTG\% 206040\% 20Spring\% 202009/Articles/T6\% 20Buyer\% 20Seller\% 20Relationships/\% 20Schurr\% dwyer 20Oh\% 20JM\% 201987\% 20Developing\% 20buyer\% 20seller\% 20relationships. pdf, accessed 12. 10. 2012, 17p.

13. Joseph Donoghue, 2011. Creating and Maintaining a Successful Supplier Relationship http://leardon. com/successful-supplier-management, San Diego, CA 92128 accessed 25. 01. 2012, takes.

14. Emiliani M. L (2010), Historical lessons in purchasing and supplier relationship management, the Journal of Management History, Emerald Group Publishing Limited, Vol.. 16 No. 1, 2010, 21 p. http://www. bobemiliani. com/papers/purch_history. pdf, accessed 21.01.2012

15. Gartner group: Buy-Side $\mathrm{B} 2 \overline{\mathrm{B}}$ E-Procurement (Application Components) Internet Commerce. Gartner Research, 2004. www. gartner. com $/ \mathrm{id}=307274$ accessed in 28. 01.2012

16. GeckerRachel, (2008), Supplier Relationship Management, Corporate Meetings Incentives, http://meetingsnet. com/corporatemeetingsincentives/m/relationship_management_1008/index 1. html accessed in 22. 12. 2011

17. Guerra Joy Andrews and She Cianchette, (2006), Just-in-Time Information, Avenue A Razorfish, Seatle, WA http://slant. avenuea-razorfish. com/1206 slant/jit. pdf, accessed in 26. 01. 2012. 
18. Gyau. , Spiller, (2008). The impact of supply chain governance structures on the interfirm relationship performance in agribusiness, Agricultural Economics, 54, (http://www. agriculturejournals. cz/publicFiles/01480. pdf, aceesat 12. 10. 2012, 10 p.

19. Hald Kim, Cordón Carlos, Vollmann Thomas, Towards an understanding of attraction in buyer-supplier relationships Industrial Marketing Management, Vol.. 38, Issue 8, pp.. 960-9702009, accessed 25. 01. 2012

20. IDC Executive Brief, (2006) Supplier Relationship Management: Moving From "Counterparties" to Collaboration, http://www. sccori. com/SCM/scm. pdf, accessed 04. 10. 2012, 7 p.

21. Itiliti, 2001, Applying the Principles of Supplier Relationship Management to Human Capital 4/26/200, http://www. opentechnologies. com/writings/itiliti White Paper. pdf, accessed in 2. 10. 2012, 9 p.

22. Lambert M. Douglas, Knemeyer Has. Michael T John Gardner, (2004), Supply chain partnerships: Model validation and implementation, Journalof business logistics, Vol.. 25, No. 2, http://www. eng. auth. $\mathrm{gr} /$ foodima/lamb7/mattas. pdf, accessed in 12. 10. 2012, 22p.

23. Source: Lambert, Douglas M. (2008), Supply Chain Management: Processes, Partnerships, Performance, Sarasota, Florida: Supply Chain Management Institute, http://www. EGF. unesp. br/ fmarins/log/materialparaleitura/-Exec Summary. pdf, accessed 12. 10. 2012, p. 20.

24. Chris Larson, 2005, Just-In-Time Supply Chain?, UPS Supply Chain Solutions http://pressroom. ups. $\mathrm{com} /$ pressroom/staticfiles/pdf/whitepaper/wp_just-in-time_supply_chain. pdf, accessed 26. 01. 2012

25. Lintukangas Katrina (2007) Theoretical frames for studying supplier relationship management in global purchasing, Lappeenranta University of Technology, School of Business, http://www. ifpsm. org/sites/default/files/4-theoretical-frames. pdf accessed 25. 01. 2012

26. Meyer, J. P. \& Allen, N. J. 1991. Of the three component conceptualization of organizational commitment. Human Resource Management Review, Vol.. 1: 61-89, http://www. sciencedirect. com/science/article/pii/105348229190011Z, accessed 01. 10. 2012

27. Mettler Tobias and Rohner, Peter (2009), Supplier Relationship Management: A Case Study in the Context of Health Care, Journal of Theoretical and Applied Electronic Commerce Research, ISSN 0718-1876, Electronic Version Universidad de Talca-Chile, VOL. 4/ISSUE 3/DECEMBER 2009/58-71, accessed 30. 01. 2012, 13p

28. Maina G, 2006, management relations, hr, www Rrbium. rrvbium. en, http://asociatia-spp. en/wpcontent/uploads/2009/11/-Management relationships. pdf, accessed in 2. 10. 2012, 11p.

29. Kerry Patterson, Joseph Grenny, David Maxfield and Ron McMillan (2007), Influencer: The Power to Change Anything, Publisher: McGraw-Hill; 1st edition ISBN-10: 007148499X, 288 p.

30. Poirier C. Charles, 2003 Supplier Relationship Management: An Advanced Supply Chain Management Technique CSC Experiences. Results. http://www. Ascinstitute . com/library/whitepapers/SRM year Advanced SCM Technique. pdf, accessed 12. 12. 2011,13p.

31. Richard Pound, (2008), Influencer - The Power to Change Anything, VitalSmarts, www. influencerbook. com, http://www. imex-frankfurt. com/documents/Influencer_Richard_Pound. pdf, 5 p.

32. Ravi R. , Menzigian K, (2003) Supplier Relationship Management: Moving From "Counterparties" to Collaboration, An IDC Executive Brief January 2003, www. sccori. com SCM/scm. pdf, accessed 25. 01. 2012

33. Rhyme Evans, When do we get to SRM?, CPO Agenda (2010), http://www. cpoagenda. com/previousarticles/autumn 2010/features/when-do-we-get-to-srm/, accessed 710.2012

34. SethiS, (2010), Enhancing Supplier Relationship Management Using SAP SRM, SAP PRESS 720 S., Auflage, $\mathrm{http} / / \mathrm{www}$. sap-press. /catalogue/buecher/htmlleseproben/gp/htmlprobID-108?GalileoSession = 63827428A5ZHm8-1J-g accessed 26.01.32012. 6p.

35. Claire Simon, Amos Gyau, 2010, The impact of price satisfaction on supplier commitment in the Australian wine supply chain, http://anzmac2010. org/proceedings/pdf/ANZMAC10Final00277. pdf, accessed 8. 10. 2012, 9 p.

36. Unknow author, The partnership model: a type of buyer-supplier relation. http://html. rincondelvago. com/thepartnership-model_a-type-of-buyer-supplier-relation. html, accessed 12. 10. 2012, 8 p.

37. Van V, M. (2006), Supplier Relationship Management Soluctions: Expected Value, Capgemini Consulting, September, 2006 accessed in 02. 10. 2012, 4 p.

38. Voge Wilf, (2009), Stakeholder Commitment: Why Is It Important?, ExecutiveBrief, http://www. projectsmart. co. uk/stakeholder-commitment-why-is-it-important. html, accessed 12. 10. 2012, 3 p. 